\title{
Molecular Analysis of Hemagglutinin Gene of Avian Influenza Viruses Isolated in 2012-2013
}

\author{
Kurniasih SW, Soejoedono RD, Mayasari NLPI \\ ${ }^{1}$ Prolab Diagnostic Laboratory PT. Sierad Produce Tbk. Jl. Raya Parung-Bogor Km. 19 Jabon Mekar, Bogor \\ ${ }^{2}$ Department of Animal Disease and Veterinary, Faculty of Veterinary Medicine, Bogor Agricultural University \\ E-mail: swk.greysfan@gmail.com
}

(received 02-03-2015; revised 23-04-2015; accepted 26-06-2015)

\begin{abstract}
ABSTRAK
Kurniasih SW, Soejoedono RD, Mayasari NLPI. 2015. Analisis molekuler gen penyandi hemaglutinin virus Avian Influenza isolat 2012-2013. JITV 20(2): 115-125. DOI: http://dx.doi.org/10.14334/jitv.v20i2.1166

Virus Avian Influenza (AI) masih menjadi penyebab utama kasus kematian unggas di Indonesia dan di seluruh dunia. Penelitian ini bertujuan untuk menentukan patogenitas serta melakukan analisis filogenetik dan jarak kekerabatan gen hemaglutinin virus-virus AI yang diisolasi di Indonesia pada tahun 2012-2013 di Jawa Barat, Jawa Tengah, dan Medan. Sampel diperoleh dari peternakan ayam yang mengalami wabah AI dan diinokulasi serta dipropagasi dalam Telur Ayam Berembrio (TAB) Specific Pathogen Free (SPF). Cairan alantois yang dipanen 5 hari setelah inokulasi diuji terhadap aktivitas hemaglutinasi. Cairan alantois dengan hemaglutinasi positif diuji lebih lanjut untuk menentukan subtipe hemaglutinin dan neuraminidase dengan real-time reverse transcription polymerase chain reaction (RRT-PCR) dan dilakukan persiapan untuk sekuensing menggunakan reverse transcription polymerase chain reaction (RT-PCR). Sekuen gen hemaglutinin dianalisis terhadap susunan asam amino di daerah cleavage site dan jarak genetik serta hubungan kekerabatan antar virus. Hasil penelitian mengindikasikan bahwa semua isolat virus tergolong ke dalam HPAI dengan pola asam amino daerah cleavage site QRESRRKKR dan QRERRRKR. Enam isolat termasuk subtipe H5N1 sedangkan 3 isolat lainnya merupakan H5Nx. Semua isolat memiliki hubungan genetik yang dekat dengan jarak genetik kurang dari 0.3 antara virus yang satu dengan yang lainnya dan juga terhadap beberapa isolat virus AI yang menyebabkan wabah-wabah sebelumnya di Indonesia.
\end{abstract}

Kata Kunci: Avian Influenza, Cleavage Site, Hemaglutinin, Patogenitas, Filogenetik

\section{ABSTRACT}

Kurniasih SW, Soejoedono RD, Mayasari NLPI. 2015. Molecular analysis of hemaglutinin gene of Avian Influenza viruses isolated in 2012-2013. JITV 20(2): 115-125. DOI: http://dx.doi.org/10.14334/jitv.v20i2.1166

Avian Influenza virus (AIV) still plays as a major cause of the death in poultry in Indonesia and around the world. The aim of this research was to determine the pathogenicity and to analyze the phylogenetic and genetic distances of hemagglutinin gene of isolated AI viruses in Indonesia in 2012-2013 particularly from West Java, Central Java, and North Sumatra. Samples were obtained from poultry farms that suffered from AI outbreaks, were inoculated and propagated in ten days old specific pathogen free (SPF) embryonated chicken eggs. Harvested allantoic fluids at 5 days after inoculation were tested for hemagglutination activity. Positive allantoic fluids were further tested to determine the hemagglutinin and neuraminidase subtype using real-time reverse transcription polymerase chain reaction (RRT-PCR) and to be prepared for sequencing using reverse transcription polymerase chain reaction (RT-PCR). The sequence of hemagglutinin genes were analyzed for the amino acid pattern of the cleavage site region and the genetic distances and relationships of those viruses. The result indicated that all of the isolates are classified as HPAI with the pattern of cleavage site regions are QRESRRKKR and QRERRRKR. Six isolates are classified as $\mathrm{H} 5 \mathrm{~N} 1$ and 3 isolates are $\mathrm{H} 5 \mathrm{Nx}$. All of the isolates have close genetic relationship with the genetic distances less than 0.3 between one to another and also with several AI viruses that caused previous outbreaks in Indonesia.

Key Words: Avian Influenza, Cleavage Site, Hemagglutinin, Pathogenicity, Phylogenetic

\section{INTRODUCTION}

Avian Influenza (AI) disease is potentially very harmful in poultry industry in Indonesia. In spite of the fact that farms had been vaccinated to prevent the outbreak, AI was sporadically still occurred in several areas in Indonesia, event in the poultry that had carried out routine vaccination. Not only in chicken, AI was also reported in ducks and the other waterfowls (Andesfha et al. 2013; OIE 2014).

Indonesian AI viruses are classified in cluster 2.1. Generally, there are 2 clusters of AI virus in the world, that are cluster 1 and cluster 2. Differences in cluster or subcluster may cause in differences of the antigenic structure between one and another virus, therefore vaccine which was used to prevent AI outbreak is 
different in one area to another. Phylogenetic analysis is very important to determine the spreads of the virus and genetic distances between AI viruses, so that the prevention and vaccination strategy could be established to prevent the upcoming AI outbreaks (Nidom et al. 2012; Wibawa et al. 2012).

The AI virus belongs to the Orthomyxoviridae family. This virus has 8 gene segments encoding 10 viral proteins. Two types of protein which have important role in pathogenicity of AI virus are hemagglutinin (HA) and neuraminidase (OIE 2014). The HA protein functions for the attachment of the virus to the host cell and to allow fusion between virus membrane and the endosomal membrane of the host cell, whereas neuraminidase has a role in releasing virion progeny into the host cell (Susanti 2008). Hemagglutinin initiates virus infection by binding the receptor of the host cell (Dharmayanti et al. 2012). The hemagglutinin gene contains cleavage site region and other components including antigenic site, receptor binding residue, receptor binding pocket, and glycolisylation site (Susanti 2008).

Cleavage site region is amino acid sequence in hemagglutinin gene where proteases of host cell cleaves the HA0 precursor into the HA1 and HA2 subunits followed by fusion between virus envelope with endosomal membrane of host cell (Perdue 2008). The proteolytic activation of HA molecule is very important in infectivity and virulence of AI virus. The specificity of HA molecule could be the determinant factor to differentiate the pathogenicity of AI virus (Dharmayanti et al. 2012). The differences in HA molecules can be based on amino acid sequence in cleavage site region. Avirulent or low pathogenic AI virus generally has single basic amino acid or arginine (R), whereas virulent or highly pathogenic strains have polybasic amino acid or multiple arginine and lysine (K) (Susanti 2008; Hewajuli \& Dharmayanti 2012). This study was aimed to determine the pathogenicity of AI virus isolated in 2012-2013 in several areas in Indonesia and to analyze the phylogenetic and genetic distances between those viruses nor with the isolate of Indonesian AI virus from previous outbreaks.

\section{MATERIALS AND METHODS}

\section{Virus isolation}

Virus isolates in this study were taken from organs of AI infected chickens (Table 1). Virus isolation was conducted based on the method of Swayne et al. (1998). Twenty grams sample were mashed and added by $80 \mathrm{ml}$ PBS containing Penicillin (10000 IU/ml), Streptomycin
(2000 $\mu \mathrm{g} / \mathrm{ml})$, Kanamycin Sulfate $(650 \mu \mathrm{g} / \mathrm{ml})$, and Amphotericin B $(20 \mu \mathrm{g} / \mathrm{ml})$. The suspension was centrifuged for 10 minutes in $5000 \mathrm{rpm}$. Supernatant obtained was used to inoculate 10 days old specific pathogen free embryonated chicken eggs with $0.2 \mathrm{ml}$ inoculum per egg. The inoculated eggs were incubated in $38-39^{\circ} \mathrm{C}$ temperature with $60-65 \%$ relatives humidity. The incubated eggs were candled to determine the mortality of embryos and dead embryos were stored in $4^{\circ} \mathrm{C}$ temperature overninght followed by allantoic fluid harvesting. The allantoic fluids were collected into sterile tube and tested for hemagglutination activity, and then stored in $-80^{\circ} \mathrm{C}$ temperature.

\section{Hemagglutination (HA) test}

Hemagglutination test was carried out by rapid hemagglutination and microtitration hemagglutination based on Office International des Epizootis (OIE) (2014).

\section{Virus identification by Real-time Reverse Transcription Polymerase Chain Reaction (RRT- PCR)}

RNAs of the virus were extracted using QIAamp Viral RNA Mini Kit (Qiagen 2010). Identification of H5 subtype was carried out by RRT-PCR using forward primer 53 5'-ACATGCCCAAGACATACTGGAA-3', reverse primer H5r-182 5'GAATTCGTCACACATTGGGTTTC-3', and probe H5 Probe-79 FAM-CACACAACGGGAAGCTCTGCGATCT-TAMRA (Chen et al. 2007). PCR composition contained $12.5 \mu 12 \times$ Quantifast Probe RTPCR Master Mix, $1 \mu \mathrm{l}$ primer H5f $0.8 \mu \mathrm{M}, 1 \mu \mathrm{l}$ primer H5r $0.8 \mu \mathrm{M}, 1 \mu \mathrm{l}$ probe $0.2 \mu \mathrm{M}, 0.25 \mu \mathrm{l}$ Quantifast RT Mix, $2 \mu$ l template RNA $100 \mathrm{ng}$, and $7.25 \mu$ l Rnase free-water with the total volume $25 \mu \mathrm{l}$. PCR process was carried out in the Qiagen Rotor-Gene Q 2plex HRM System with temperature for reverse transcription reaction was $50^{\circ} \mathrm{C}$ for 10 minutes, initiation/activation of $95^{\circ} \mathrm{C}$ for 5 minutes, denaturation of $95^{\circ} \mathrm{C}$ for 15 second, and combination of annealing-extension was $52^{\circ} \mathrm{C}$ for 60 second with 40 times of the PCR cycle. Identification of $\mathrm{N} 1$ subtype was carried out by the same method using forward primer N1F2 5'GTTTGAGTCTGTTGCTTGGTC-3', reverse primer N1R1 5'-TGATAGTGTCTGTTATTATGCC-3', and N1-probe FAM-TTGTATTTCAATACAGCGACTAMRA (Payungpon et al. 2006) with annealing/extension temperature was $50^{\circ} \mathrm{C}$ for 60 second. 
Table 1. List of virus isolates 2012-2013

\begin{tabular}{llll}
\hline \hline Isolate & Poultry & Origin & Year \\
\hline A/Ck/Parung Panjang/Prl/2012 & Native chicken & Tangerang & 2012 \\
A/Ck/Cigudeg/Prl/2013 & Native chicken & Bogor & 2013 \\
A/Ck/Lyr.Gunungsindur/Prl/2013 & Layer & Bogor & 2013 \\
A/Ck/Gunungsindur/Prl/2013 & Broiler & Bogor & 2013 \\
A/Ck/Cianjur/Prl/2013 & Broiler & Cianjur & 2013 \\
A/Ck/Legok/Prl/2013 & Broiler & Tangerang & 2013 \\
A/Ck/Medan/Prl/2013 & Broiler & Medan & 2013 \\
A/Dk/Pakijangan/Prl/2013 & Duck & Brebes & 2013 \\
A/Dk/Brebes/Prl/2013 & Duck & Brebes & 2013
\end{tabular}

\section{Reverse Transcription Polymerase Chain Reaction (PCR) for sequencing}

Reverse Transcription-PCR reaction which was used in the sequencing process contained of $10 \mu \mathrm{l} 5 \times$ Qiagen OneStep RT-PCR Buffer, $2 \mu \mathrm{l}$ dNTP Mix 10 $\mu \mathrm{M}, 1.5 \mu \mathrm{l}$ primers $0.6 \mu \mathrm{M}, 2 \mu \mathrm{l}$ Qiagen OneStep RTPCR Enzyme Mix, $10 \mu \mathrm{l}$ Q solution, $2 \mu \mathrm{l}$ RNA 1-2 $\mu \mathrm{g}$, and $21 \mu \mathrm{l}$ RNase-free water with total volume was 50 $\mu 1$. RT-PCR program consisted of reverse transcription $50^{\circ} \mathrm{C}$ for 30 minutes, pre-denaturation $95^{\circ} \mathrm{C}$ for 15 minutes, 40 cycles consisted of denaturation $94^{\circ} \mathrm{C}$ for 30 second, annealing $53^{\circ} \mathrm{C}$ for 60 second, and extension $72^{\circ} \mathrm{C}$ for 60 second, with the final extension $72^{\circ} \mathrm{C}$ for 10 minutes.

PCR reactions was carried out with 3 different pairs of primer including forward primer HA01 5'TGGAGAAAATAGTGCTTCTTCTTGC-3' and reverse primer HA645 5' GGAAATATAGGTGGTTGGGTTTTG-3' (Susanti 2008), forward primer HA548F 5'CCAACCAGAGAAGGATCTTTTGG-3' and reverse HA1215R 5'-ACTAGGCCTCAAACTGAGTGTTC-3' (Susanti 2008), primer H5-1 5'GCCATTCCACAACATACACCC-3' and H5-3 5'CTCCCCTGCTCATTGCTA-3' (WHO 2005), following with the electrophoresis of the PCR products.

\section{Sequencing}

Purification of PCR products and sequencing process were done by PT Genetika Science Jakarta and 1st Base Malaysia. The DNA sequences were used for phylogenetic analysis and to determine the pathogenicity of the virus.

\section{Phylogenetic analysis}

Phylogenetic and genetic distance analysis among isolates were carried out by multiple alignment ClustalW in BioEdit (Alzohairy 2011). The construction of phylogenetic tree was done by MEGA 5.05 version (Tamura et al. 2011).

\section{RESULT AND DISCUSSION}

\section{Death of embryos after AI virus inoculation}

Isolate 1, 2, 4, 6, 7, and 8 caused embryo's death in 24-48 hours after the inoculation, whereas isolate 3, 5, and 9 caused embryo's dead after 48 hours (Table 2 and Table 3). The death of embryos was correlated with the virulence and pathogenicity of the virus. Swayne et al. (1998) clarified that pathogenic AI virus can cause embryo's death in 24-48 hours after $0.2 \mathrm{ml}$ inoculation of the virus into allantoic cavity. The death of embryos occurred in 24-48 hours after inoculation in this study indicated that isolate $1,2,4,6,7$, and 8 were pathogenic AI virus. Isolate 3, 5, and 9 caused embryo death after 48 hours. Embryo's death is related to the capability of hemagglutinin gene to be cleaved by the host cell protease. AI virus with pathogenic cleavage site but killed embryos in more than 36 hours was assumed as AI virus which had lost its pathogenicity to its native host. Parallel with the result of Kencana et al. (2014) the death of embryos as the result of non-pathogenic AI virus infection occurred in 3rd day post inoculation. This phenomenon was suspected to be occurred in isolate 3,5 , and 9 . The capability of HA protein to be cleaved by host cell protease determines the spreads of 
Table 2. Observation of the embryo post AI virus inoculation

\begin{tabular}{lllll}
\hline \hline$<24$ hours & $24-48$ hours & $48-72$ hours & $72-96$ hours & $>96$ hours \\
\hline live & 3 death & - & - & - \\
live & 3 death & - & - & - \\
live & 3 live & 2 death, 1 live & 1 death & - \\
live & 3 death & - & - & - \\
live & 3 live & 2 death, 1 live & 1 death & - \\
live & 3 death & - & - & - \\
live & 3 death & - & - & - \\
live & 3 death & - & - & - \\
live & 3 live & 3 death & - & - \\
live & 3 live & 3 live & 3 live & 3 live \\
\hline
\end{tabular}

Table 3. The death of embryo post AI virus inoculation

\begin{tabular}{ll}
\hline \hline Isolate & Death of embryo \\
\hline A/Ck/Parung Panjang/Prl/2012 & $<48$ hours \\
A/Ck/Cigudeg/Prl/2013 & $<48$ hours \\
A/Ck/Gunungsindur/Prl/2013 & $<48$ hours \\
A/Ck/Legok/Prl/2013 & $<48$ hours \\
A/Ck/Medan/Prl/2013 & $<48$ hours \\
A/Dk/Pakijangan/Prl/2013 & $<48$ hours \\
A/Ck/Lyr.Gunungsindur/Prl/2013 & $>48$ hours \\
A/Ck/Cianjur/Prl/2013 & $>48$ hours \\
A/Dk/Brebes/Prl/2013 & $>48$ hours \\
\hline
\end{tabular}

AI virus in chorioallantoic membrane of the embryo. AI virus with HA protein that capable to be cleaved by proteases has the capacity to penetrate the 3 germinal layers of the membranes and enter to the blood vessels (Lebas et al. 2013) and the visceral organs (Krauss et al. 2012). Hemagglutinin from pathogenic AI virus can facilitate the virus spreading from the allantoic space to the deeper mesenchymal vascularization layer of the chorioallantoic membrane, causes the extensive virus infection, contrary with the hemagglutinin from nonpathogenic AI virus that only causes infection in allantoic membrane and inside the allantoic cavity (Feldmann et al. 2000).

\section{Correlation of the virus amount with hemagglutination activity and virulence of the virus}

Hemagglutination test is used to determine the quantity of the virus which agglutinates the red blood cell (RBC) and it is a method which is used in the screening of the existence of a causative agent of hemagglutination such as influenza A virus in the isolates harvested from allantoic fluids. The progeny of AI virus which is released from the infected cells can be determined by hemagglutination test (Killian 2014). Agglutination of RBC by $\mathrm{AI}$ virus is mediated by reaction between receptor binding site of hemagglutinin molecule with sialic acid receptor of the host cell. Hemagglutinin is a part of virus which will attach on the chicken's RBC receptor causing the agglutination. The attachment would form a protoplasm bridges which eventually form a mass that precipitates in the bottom of the microplate These activities will be the basis in the hemagglutination test to determine the existence of the virus that agglutinates $\mathrm{RBC}$ in the allantoic fluids (Natih et al. 2010). HA titre is correlated with the amount of virus in the allantoic fluids after virus inoculation. HA titre shows negative result if the quantity of the virus is less than $10^{6}$ embryo infectious dose $\left(\mathrm{EID}_{50}\right) / \mathrm{ml}$ (Kencana et al. 2014). This test is quantitatively, the value of $1 \mathrm{HAU}$ is equal with $10^{7}$ particles of the virus (Killian 2014). Positive reaction of hemagglutination test is occurred if the HA titre is valued $\geq 2$ HAU (Koratkar et al. 2014). HA titre of the isolates in this study (Table 4) were 18-1382 HAU with the highest level was isolate 8 (1382 HAU) and the lowest one was isolate 3 (18 HAU). According to Wanasawaeng et al. (2008), chicken's embryo which was inoculated with virulent AI virus, commonly died within 32 hours with infectivity titre around 7.3-9.0 $\log 2$ HA titre or 128-512 HAU. Lang et al. (2011) mentioned that the highest HA titre existed in the allantoic fluids of the embryo harvested at the 1st and 2nd day of the AI virus isolation indicating the increasing of the newly forming infective virion. It could be assumed that isolate 1, 2, 4, 6, 7, and 8 in this study were virulent AI virus with the HA titre ranged 343-1382 HAU. 
Table 4. Hemagglutination (HA) titre

\begin{tabular}{ll}
\hline \hline Isolate & HA Titre (HAU) \\
\hline A/Ck/Parung Panjang/Prl/2012 & 512 \\
A/Ck/Cigudeg/Prl/2013 & 589 \\
A/Ck/Gunungsindur/Prl/2013 & 343 \\
A/Ck/Legok/Prl/2013 & 1024 \\
A/Ck/Medan/Prl/2013 & 1382 \\
A/Dk/Pakijangan/Prl/2013 & 512 \\
A/Ck/Lyr.Gunungsindur/Prl/2013 & 18 \\
A/Ck/Cianjur/Prl/2013 & 42 \\
A/Dk/Brebes/Prl/2013 & 74 \\
\hline
\end{tabular}

Moresco (2010) declared that low pathogenic AI virus showed the HA titre less than the amount that could be detected in the allantoic fluids from virus isolation, whereas Koratkar et al. (2014) said that positive reaction of the hemagglutination test occurred if HA titre was $\geq 2 \mathrm{HAU}$. Isolate 3,5 , and 9 had positive $\mathrm{HA}$ titre or valued as $\geq 2 \mathrm{HAU}$, but the HA titre of the isolates were low (around 18-74 HAU). It could be suspected that isolate 3,5 , and 9 were AI viruses which may have experienced a mutation or reasortion that caused the unability to replicate in the host cell to reach the appropriate hemagglutination titre or its hemagglutination activities were lower.

\section{Subtype of avian influenza viruses isolated in 2012- 2013}

Real Time RT-PCR results threshold cycle $(\mathrm{Ct}$ value) which is the amount of PCR cycle at the time when fluorescence increases and can be detected significantly at the early stage of the positive samples.
Threshold cycle represents the change of the cycle number at the time when the positive amplification reaction could be measured (Payungporn et al. 2006). The RRT-PCR results positive samples if the Ct value $<33$, whereas it is negative if $\mathrm{Ct}$ value $>35$ (SADC 2010). In this study, 9 isolates were positive H5. Six from the 9 isolates were positive $\mathrm{N} 1$, therefore the six isolates (isolate 1, 2, 4, 6, 7, and 8) could be classified into $\mathrm{H} 5 \mathrm{~N} 1$ subtype, whereas the other 3 isolates (isolate 3 , 5, and 9) were $\mathrm{H} 5$ subtype aside of $\mathrm{N} 1$ ( $\mathrm{H} 5 \mathrm{Nx}$ subtype). The results of the RRT-PCR test were presented in the Table 5.

The results of RRT-PCR in this study showed $10^{6}$ $10^{8}$ copies of RNA of the H5 positive isolates and $10^{5}$ $10^{8}$ copies of RNA of the N1 positive isolates. RRTPCR product was detected using specific sequence probe to amplify only the specific target. Specific HA probe could be used for the quantification of the virus with different subtypes in one virus mixture (OIE 2014; Spackman 2014). The amount of RNA copy that could not be read at the N1 RRT-PCR test from isolate 3, 5, and 9 indicated that there were no amplification occured, and the isolates were considered to be negative N1. However, Ct value and the amount of RNA copy did not show correlation with the result of virus isolation and hemagglutination test. The H5Nx isolates apparently had $\mathrm{Ct}$ value and RNA copy comparable with isolates from H5N1 subtype. This was possible because RRT-PCR test has the high sensitivity and specificity that can detect and amplify the very small quantity of RNA. The difference in AI virus detection between RRT-PCCR and virus isolation is caused by the difference of the ability of both test to detect the parts of the virus. Virus isolation only detects live virus and cannot detect virus that had been inactivated or had experienced other treatments, whereas the RRT-PCR can detect live or inactivated virus (Spackman 2014)

Table 5. Threshold cycle (Ct value) and number of RNA copy of H5 and N1 in RRT-PCR

\begin{tabular}{|c|c|c|c|c|}
\hline \multirow{2}{*}{ Isolate } & \multicolumn{2}{|c|}{$\mathrm{Ct}$} & \multicolumn{2}{|c|}{ RNA copy $/ \mu 1$} \\
\hline & H5 & N1 & H5 & N1 \\
\hline A/Ck/P.Panjang/Prl/2012 & 20.02 & 13.90 & 1381543 & 283112136 \\
\hline A/Ck/Cigudeg/Prl/2013 & 17.22 & 15.16 & 63815531 & 125437247 \\
\hline A/Ck/Gunungsindur/Prl/2013 & 16.54 & 23.75 & 92686366 & 481532 \\
\hline A/Ck/Legok/Prl/2013 & 15.94 & 16.12 & 128404046 & 67493217 \\
\hline $\mathrm{A} / \mathrm{Ck} / \mathrm{Medan} / \mathrm{Prl} / 2013$ & 16.18 & 15.14 & 112597534 & 126602979 \\
\hline A/Dk/Pakijangan/Prl/2013 & 17.06 & 17.81 & 6975631 & 22448560 \\
\hline A/Ck/Lyr.Gnsindur/Prl/2013 & 16.89 & tba & 76147115 & tba \\
\hline A/Ck/Cianjur/Prl/2013 & 17.85 & tba & 45025043 & tba \\
\hline $\mathrm{A} / \mathrm{Dk} / \mathrm{Brebes} / \mathrm{Prl} / 2013$ & 20.54 & tba & 10331331 & tba \\
\hline
\end{tabular}

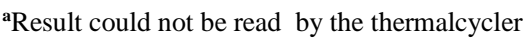




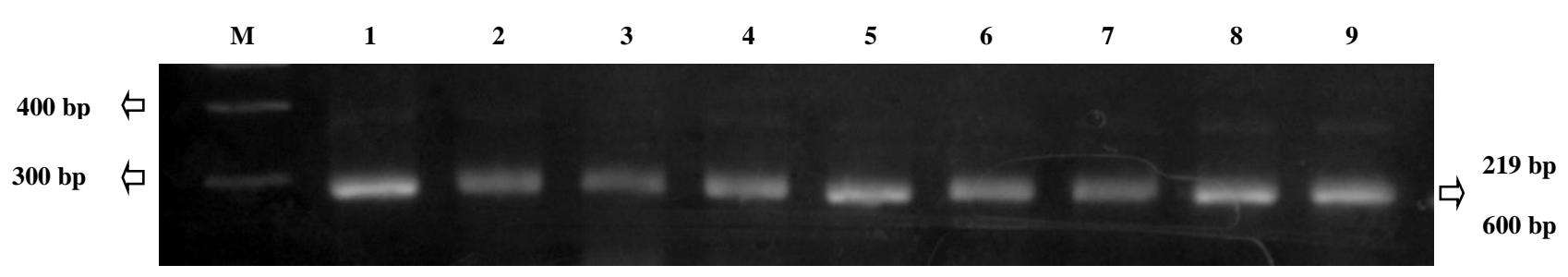

M. Marker 1kb; 1. A/Ck/Parung Panjang/Prl/2012; 2. A/Ck/Cigudeg/Prl/2013; 3. A/Ck/Lyr.Gunungsindur/Prl/2013;

4. A/Ck/Gunungsindur/Prl/2013; 5. A/Ck/Cianjur/Prl/2013; 6. A/Ck/Legok/Prl/2013; 7. A/Ck/Medan/Prl/2013; 8. A/Dk/Pakijangan/Prl/2013; 9. A/Dk/Brebes/Prl/2013

Figure 1. PCR product of H5-1 H5-3 primer amplification

In the other side, in connection with the mortality of the embryo and HA titre, the results of the RRT-PCR test had a correlation with virus isolation and hemagglutination test. RRT-PCR test, technically accurately measured RNA quantity correlated with HA content (Spackman \& Suarez 2005). Isolate 3, 5, and 9 showed embryo death after 48 hours and had lower HA titre $(18,42$, and $74 \mathrm{HAU}$ respectively) were $\mathrm{H} 5 \mathrm{Nx}$ subtype, therefore could be assumed that only isolates classified in H5N1 subtype that could kill embryo in 24-48 hours and had higher HA titre (343-1382 HAU) compared to H5Nx subtype.

\section{Amino acid sequences of the Cleavage site of hemagglutinin gene}

The electrophoresis of the PCR product is presented in Figure 1. Sequencing result of the PCR products with primer that specificaly amplified cleavage site region of hemagglutinin gene showed sequence of repeated arginine (R) and lysine (K) amino acid (Table 6). AI virus with polybasic amino acid sequence of arginin or lysine are classified as pathogenic (Gohrbandt et al. 2011; Li et al. 2011). Virulence characteristic of AI that distinguish HPAI from LPAI is the ability of the virus to be cleaved by proteases which could be found in almost all type of host cells. Hemagglutinin gene produced as single polypeptide is cleaved into HA1 and HA2 subunit before the virus become infectious. This cleavage process is important for the fusion domain to be active during virus replication process and facilitate AI virus infection to the host cell. Generally, cleavage process is conducted by trypsin or trypsin-like proteases which cleaved HA protein due to the recognition of single arginine. Monobasic (single arginine) amino acid sequence could be cleaved by tryptase produced by ephitelial cell of gastrointestinal and respiratory tracts, therefore the AI virus infection is restricted in gastrointestinal and respiratory organs. However, if polybasic amino acid or repeated arginine or lysine are existed, the cleavage site becomes accessible to furin or other ubiquitous proteases, such as proprotein convertase 6 (PC6) in the Golgy that is found in most
Table 6. Amino acid sequence of hemagglutinin gene on cleavage site

\begin{tabular}{lc}
\hline \hline Isolate & Amino acid pattern \\
\hline A/Ck/Parung Panjang/Prl/2012 & QRESRRKKRG \\
A/Ck/Cigudeg/Prl/2013 & QRESRRKKRG \\
A/Ck/Gunungsindur/Prl/2013 & QRESRRKKRG \\
A/Ck/Legok/Prl/2013 & QRESRRKKRG \\
A/Ck/Medan/Prl/2013 & QRESRRKKRG \\
A/Dk/Pakijangan/Prl/2013 & QRESRRKKRG \\
A/Ck/Lyr.Gunungsindur/Prl/2013 & QRERRRKRG \\
A/Ck/Cianjur/Prl/2013 & QRERRRKRG \\
A/Dk/Brebes/Prl/2013 & QRERRRKRG \\
\hline
\end{tabular}

cells and so the infection could be occurred in the various tissues and infect systemically. Therefore, amino acid sequence in the cleavage site determines the pathogenicity of AI virus, as AI virus could be classified into highly pathogenic (HPAI) or low pathogenic (LPAI) (Bogs et al. 2010; Gohrbandt et al. 2011). The cleavage site region of hemagglutinin gene plays very important role in producing infectious viral progeny during the AI virus infection (Leijon et al. 2011). Polybasic amino acid or arginine and lysine in the hemagglutinin of $\mathrm{H} 5 \mathrm{~N} 1 \mathrm{AI}$ have a role in systemic infection, so that AI virus could be isolated from blood, brain, nerve, cerebrospinal fluid, cornea, heart, lungs, kidney, pancreas, intestine, caecum, and feces (Yamamato et al. 2010; Kim et al. 2015).

The research of Wibawa et al. (2011) in ducks in Central Java in 2007-2008 showed amino acid patterns of cleavage site were QRERRRKKR, QRESRRKRR, QRESRRRKR, QKESRRKKR, and QRESRRKKR. Wibawa et al. (2012) also isolated AI virus that caused outbreak in duck in several areas in Central Java, Yogyakarta, and East Java in September-November 2012 and showed amino acid patterns of the cleavage site was QRERRRKR. Research of Andhesfa et al. (2013) of birds in Central Java, Yogyakarta, and East 


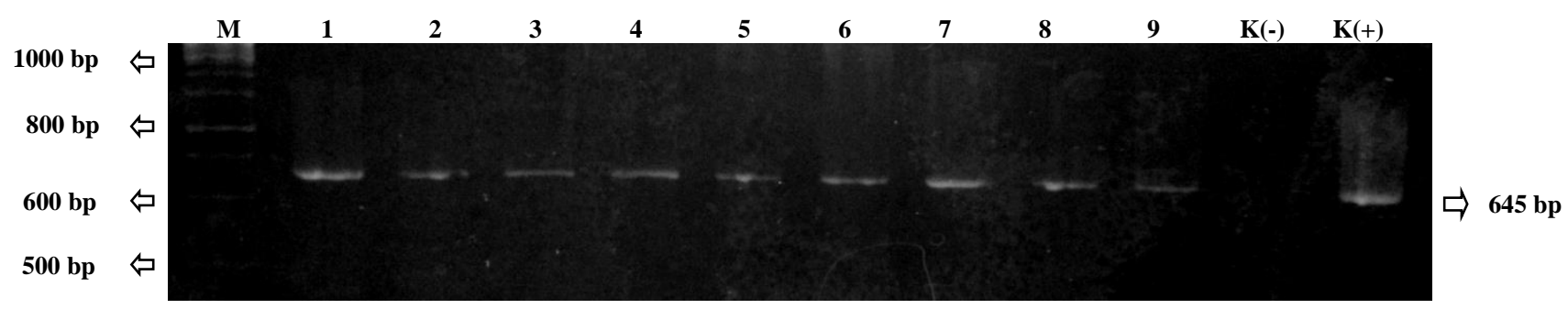

M. Marker 1kb; 1. A/Ck/Parung Panjang/Prl/2012; 2.A/Ck/Cigudeg/Prl/2013; 3. A/Ck/Lyr.Gunungsindur/Prl/2013

4. A/Ck/Gunungsindur/Prl/2013; 5. A/Ck/Cianjur/Prl/2013; 6. A/Ck/Legok/Prl/2013; 7. A/Ck/Medan/Prl/2013; 8. A/Dk/Pakijangan/Prl/2013; 9. A/Dk/Brebes/Prl/2013; K(-). Negative control, K(+). Positive control

Figure 2. PCR product of HA01-HA645 primer amplification

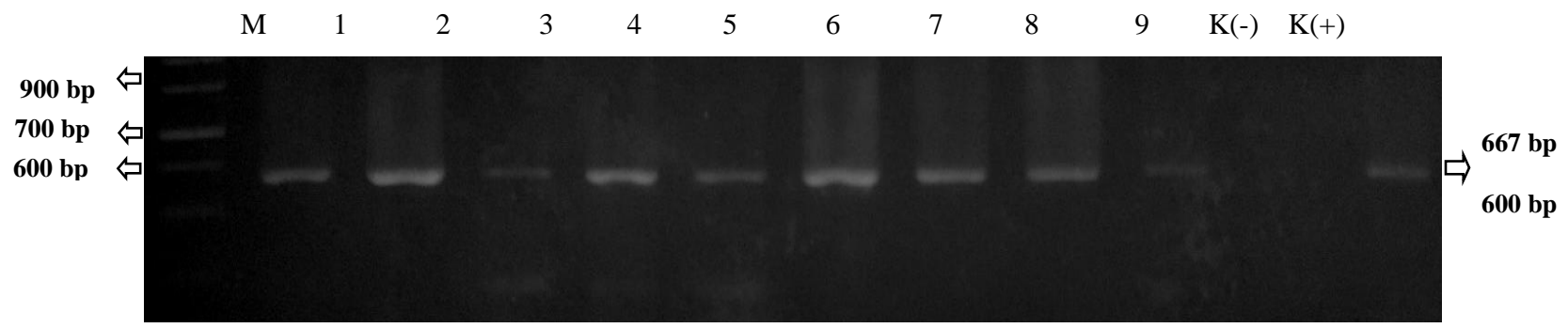

M. Marker 1kb, 1. A/Ck/Parung Panjang/Prl/2012; 2.A/Ck/Cigudeg/Prl/2013; 3. A/Ck/Lyr.Gunungsindur/Prl/2013;

4. A/Ck/Gunungsindur/Prl/2013; 5. A/Ck/Cianjur/Prl/2013; 6. A/Ck/Legok/Prl/2013; 7. A/Ck/Medan/Prl/2013;

8. A/Dk/Pakijangan/Prl/2013; 9. A/Dk/Brebes/Prl/2013; K(-). Negative control, K(+). Positive control

Figure 3. PCR product of H548F-H1215R primer amplification

Java in 2011-2012 also explained that AI virus which successfully isolated had amino acid pattern of the cleavage site of QRESRRKKR and QRERRRKR and caused AI outbreaks in those areas.

Sequencing analysis result of the hemagglutinin cleavage site of the AI viruses in this study showed that 6 isolates (H5N1) had amino acid pattern of QRESRRKKR and 3 isolates (H5Nx) had QRERRRKR. QRESRRKKR pattern by previous scientist was reported to be found in waterfowls, whereas in this study the pattern was found in AI isolate which cause outbreaks in broiler chicken (A/Ck/Gunungsindur/Prl/2013, A/Ck/Legok/Prl/2013, $\mathrm{A} / \mathrm{Ck} / \mathrm{Medan} / \mathrm{Prl} / 2013)$, native chicken (/Ck/Parung Panjang/Prl/2012, A/Ck/Cigudeg/Prl/2013), and duck (A/Dk/Pakijangan/Prl/2013). It was assumed that AI virus that caused the outbreaks were came from ducks or other waterfowls wandering around the farm or kept in backyard which clinically was healthy and became as a source of transmission of AI virus. WHO (2011) and Coker et al. (2014) explained that wild or domestic waterfowls has important role in AI virus transmission to the other domestic birds. Wild waterfowls is a natural host of the type A influenza virus and plays important role in the ecology and virus propagation. Commonly from the natural host, the type A influenza virus could be transmitted to the other birds (Pillai et al. 2010). AI virus is replicated in epithelial cells of the intestinal track of the wild waterfowls. Virus excretion through feces could become the source of transmission of AI virus to other domestic birds. Duck's living place which is close to the water environment makes it possible to be a media of virus transmission through the water (Hewajuli \& Dharmayanti 2012). When AI virus has been transmitted by duck to the other birds, there would be a high morbidity, clinical symptoms, and mortality rate (Henning et al. 2010; Leijon et al. 2011). This also showed that waterfowls which clinically healthy play as an evolution place of AI virus and by time the virus become more pathogen (Henning et al. 2010; Hewajuli \& Dharmayanti 2012).

The QRERRRKR amino acid sequence of 3 isolates of $\mathrm{H} 5 \mathrm{Nx}$ resembled with the common pattern existed in duck, is in accoordance with Wibawa et al. (2012). In this research, the same pattern was found in commercial layer (A/Ck/Lyr.Gunungsindur/Prl/2013), commercial broiler (A/Ck/Cianjur/Prl/2013), and duck (A/Dk/Brebes/Prl/2013). It was assumed that the waterfowls also played as a source of transmission in those cases. However, those 3 isolates had phenotypic difference with another 6 isolates in case of the longer period was needed to cause embryo death and the lower HA titre. There was a possibility that the viruses were came from low pathogenic virus which had undergone mutation or reasortion, so that had amino acid pattern in the cleavage site of hemagglutinin gene resembled with the pattern of the pathogenic virus. Gohrnandt et al. (2011) explained that a HPAI strain may be an 
acquisition of a non-pathogenic AI strain which had experienced a mutation and had cleavage site region that characterized pathogenic AI strain. In spite of it did not show clinical symptoms, the waterfowls could continuously excrete virus, so it could be potentially mode of spreading pathogenic virus to another birds ( $\mathrm{Li}$ et al. 2011). Zhao et al. (2012) said despite an AI virus having cleavage site with the amino acid pattern characterized of high patogenicity AI virus, however phenotypically the virus could be characterized as low pathogenicity.

The fact that 3 isolates of $\mathrm{H} 5 \mathrm{Nx}$ had phenotypic resembling low pathogenic AI virus but evidently having amino acid sequence of QRERRRKR which was characterized as high pathogenic virus, confirmed the assumption that $\mathrm{AI}$ viruses that had been isolated in Indonesia were pathogenic viruses, in line with WHO (2011) and Wibawa et al. (2012) which reported that AI viruses circulated in Indonesia since first report in 2003 were highly pathogenic avian influenza (HPAI) H5N1 subtype and that the prevalence of low pathogenic AI virus in Indonesian poultry had not been found yet.

\section{Phylogenetic Analysis and Genetic Distance}

The electrophoresis of the PCR product is shown in Figure 2 and Figure 3. Phylogenetic analysis and genetic distances which described in Figure 4 and Table 7 showed that AI isolates in this study were divided into 2 clusters. Isolate 1, 2, 4, 6, and 7 were in same cluster with AI isolated from chicken in Banten in 2008
(GenBank: GU183461), Legok 2003 (GenBank: GU052426.1), and AI Legok isolated by Prolab in 2008. The Legok 2003 was the isolate obtained from the first AI outbreak in Indonesia, so it was assumed that isolate 1, 2, 4, 6, and 7 were the descendant of the AI virus that caused the first outbreak and had not a meaningful genetic mutation. Genetic distance between the isolates ranged $0.042-0.081$. Isolate 8 and 9 which were isolated from duck and isolate 3 and 5 which were isolated from layer and broiler chicken had genetic similarity with duck isolated from Tegal 2012 (GenBank: KC417274.1) and Blitar 2012 (GenBank: $\mathrm{KC} 417277.1)$. Genetic distance between the isolates was 0.003-0.029. The genetic similarity between AI viruses isolated from chicken with those were isolated from waterfowls was suspected due to of the existence of waterfowls reared around the chicken farms resulting in AI transmission from the waterfowls to the chicken. Henning et al. (2010) said that waterfowls is the source of transmission of AI virus to another surrounding birds. Water as a living place of the waterfowls become the media and source of AI virus infection. The fact that waterfowls are the main source of AI virus infection makes the implementation of prevention and control programs of AI virus become more difficult to be conducted (Hewajuli \& Dharmayanti 2012). The genetic distance between the 2 clusters in this study was $0.062-0.131$, this showed that all of the isolates in the 2 clusters still had close relationship with the coefficient of phylogeny was $<0.3$ and homology was $>97 \%$ (Wibawa et al. 2012).

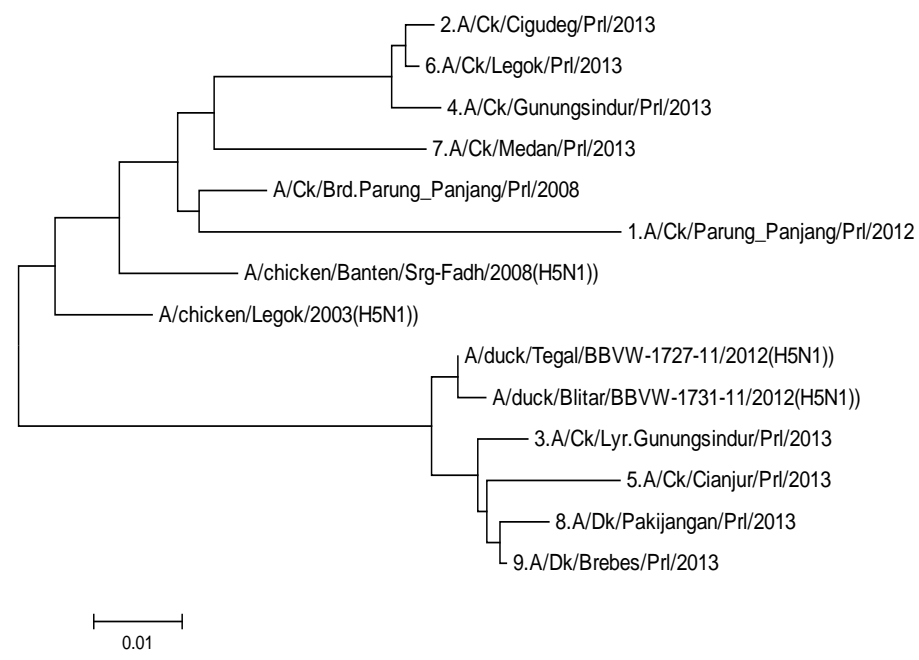

Figure 4. Phylogenetic tree of the hemagglutinin gene of AI viruses isolate 1-9 compare with AI virus from the previous outbreaks 
Table 7. Genetic distances of the hemagglutinin gene between AI viruses used in the research with AI viruses from previous outbreaks

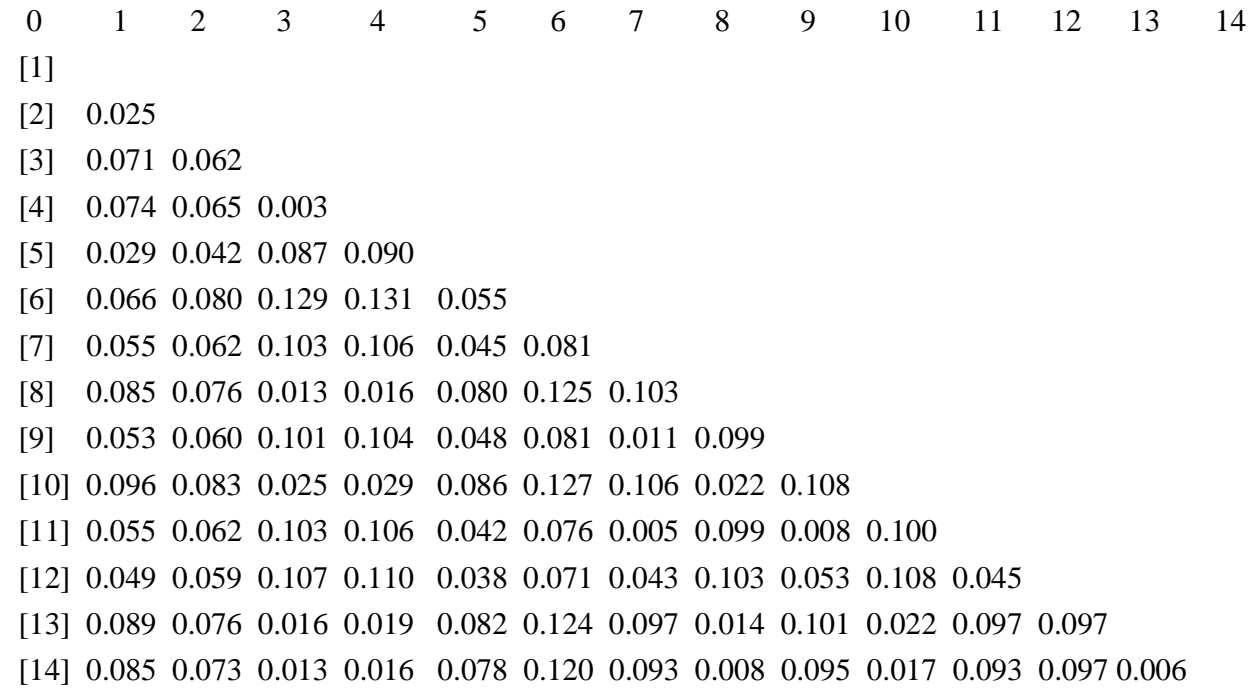

[1] \#A/chicken/Banten/Srg-Fadh/2008(H5N1)); [2] \#A/chicken/Legok/2003(H5N1)); [3] \#A/duck/Tegal/BBVW-1727-11/2012(H5N1)); [4] \#A/duck/Blitar/BBVW-1731-11/2012(H5N1)); [5] \#A/Ck/Brd.Parung_Panjang/Prl/2008; [6] \#1.A/Ck/Parung_Panjang/Prl/2012;

[7] \#2.A/Ck/Cigudeg/Prl/2013; [8]\#3.A/Ck/Lyr.Gunungsindur/Prl/2013; [9] \#4.A/Ck/Gunungsindur/Prl/2013; [10] \#5.A/Ck/Cianjur/Prl/2013; [11] \#6.A/Ck/Legok/Prl/2013; [12] \#7.A/Ck/Medan/Prl/2013; [13] \#8.A/Dk/Pakijangan/Prl/2013; [14] \#9.A/Dk/Brebes/Prl/2013

\section{CONCLUSION}

All of the isolates used in this study were highly pathogenic avian influenza (HPAI). Six isolates were classified into $\mathrm{H} 5 \mathrm{~N} 1$ subtype, whereas the other 3 isolates were included into H5Nx subtype. Phylogenetic analysis and genetic distance between viruses showed that isolates in this study were divided into 2 clusters and still had close relationship.

\section{ACKNOWLEDGEMENTS}

This research was funded and facilitated by PT. Sierad Produce Tbk. and also supported by staffs of Integrated Laboratory of Department of Animal Diseases and Veterinary Public Health of Faculty of Veterinary of Bogor Agricultural University. The author also gratefully appreciates the support received from friends and all staffs of Prolab Diagnostic Laboratory for moral support and cooperation.

\section{REFERENCES}

Alzohairy AM. 2011. BioEdit: an important software for molecular biology. GERF Bull Biosci. 2:60-61.

Andesfha E, Ramlah, Natih KKN, Djusa ER, Mucharini H. 2013. Identifikasi molekuler dinamika genetik virus avian influenza subtipe H5N1 clade 2.1.3 dan 2.3.2. Buletin Pengujian Mutu Obat Hewan. 20:34-45.
Bogs J, Veits J, Gohrbandt S, Hundt J, Stech O, Breithaupt A, Teifke JP, Mettenleiter TC, Stech J. 2010. Highly pathogenic $\mathrm{H} 5 \mathrm{~N} 1$ influenza viruses carry virulence determinants beyond the polybasic hemagglutinin cleavage site. PLoS One. 5:e11826:1-8.

Chen W, He B, Li C, Zhang X, Wu W, Yin X, Fan X,Wang J. 2007. Real-time RT-PCR for H5N1 avian influenza A virus detection. J Med Microbiol. 56:603-607.

Coker T, Meseko C, Odaibo G, Olaleye D. 2014. Circulation of low pathogenic avian influenza subtype $\mathrm{H} 5 \mathrm{~N} 2$ virus in ducks at a live bird market in Ibadan, Nigeria. Infect Dis Pover. 3:1-6

Dharmayanti NLPI, Diwyanto K, Bahri S. 2012. Mewaspadai perkembangan Avian Influenza (AI) dan keragaman genetikvirus AI/H5N1 di Indonesia. Pengembangan Inovasi Pertanian. 5:124-141.

Feldmann A, Schafer MKH, Garten W, Klenk HD. 2000. Targeted infection of endothelial cells by avian influenza virus A/FPV/Rostock/34 (H7N1) in chicken embryos. J Virol. 74:8018-8027.

Gohrbandt S, Veits J, Hundt J, Bogs J, Breithaupt A, Teifke JP, Weber S, Mettenleiter TC, Stech J. Amino acids adjacent to the hemagglutinin cleavage site are relevant for virulence of avian influenza viruses of subtype H5. J Gen Virol. 92:51-59.

Henning J, Wibawa H, Morton J, Usman TB, Junaidi A, Meers J. 2010. Scavenging ducks and transmission of highly pathogenic avian influenza, Java, Indonesia. Emerg Infect Dis. 16:1244-1250. 
Hewajuli DA, Dharmayanti NLPI. 2012. Hubungan AI dan unggas air dalam menciptakan keragaman genetik serta peran unggas air sebagai reservoir pada penyebaran virus AI. Wartazoa. 22:12-23.

Killian ML. 2014.Hemagglutinin assay for influenza virus. Meth Mol Biol. 1161:3-9.

Kencana GAY, Suartha IN, Nurhandayani A, Ramadhan M. 2014. Kepekaan telur spesific pathogen free dan clean egg terhadap virus flu burung. J Vet. 15:87-93.

Kim HR, Kwon YK, Jang I, Lee YJ, Kang HM, Lee EK, Song BM, Lee HS, Joo YS, Lee KH, Lee HK, Baek KH, Bae YC. 2015. Pathologic changes in wild birds infected with highly pathogenic avian influenza A (H5N8) viruses, South Korea, 2014. Emerg Infect Dis. 21:775780.

Koratkar SS, Pawar SD, Shelke VN, Kale SD, Mishra AC. 2014. Pathogenicity of avian influenza H11N1 virus isolated from wild aquatic bird Eurasian spoonbill (Platalea leucorodia). Indian J Med Res. 139:782-785.

Krauss S, Walker D, Webster RG. 2012. Influenza virus isolation. In: Influenza Virus: Methods and Protocols. Kawaoka Y, Neumann G, editors. Methods Mol Biol. 865:11-24.

Lang V, Marjuki H, Krauss SL, Webby RJ, Webster RG. 2011. Different incubation temperatures affect viral polymerase activity and yields of low-pathogenic avian influenza viruses in embryonated chicken eggs. Arch Virol. 156:987-994.

Lebas NZ, Shahsavandi S, Mohammadi A, Ebrahimi MM, Bakhshesh M. 2013. Replication efficiency of influenza A virus H9N2: a comparative analysis between different origin cell types. Jundis J Microbiol. 6:1-5.

Leijon M, Ullman K, Thyselius S, Zohari S, Pedersen JC, Hanna A, Mahmood S, Banks J, Slomka MJ, Belak S. 2011. Rapid PCR-based molecular pathotyping of H5 and $\mathrm{H} 7$ avian influenza viruses. J Clin Microbiol. 49:3860-3873.

Li Y, Liu L, Zhang Y, Duan Z, Tian G, Zeng X, Shi J, Zhang L, Chen H. 2011. New avian influenza virus (H5N1) in wild birds, Qinghai, China. Emerg Infect Dis. 17:265267.

Moresco KA. 2010. Evaluation of avian embryos and cell culture for isolation and propagation of low pathogenicity avian influenza virus (Tesis). [Athens (IA)]: University of Georgia.

Natih KKN, Soejoedono RD, Wibawan IWT, Pasaribu FH. 2010. Preparasi imunoglobulin G kelinci sebagai antigen penginduksi antibodi spesifik terhadap virus Avian Influenza H5N1 strain Legok. J Vet. 11:96-106.

Nidom CA, Yamada S, Nidom RV, Rahmawati K, Alamudi MY, Kholik, Indrasari S, Hayati RS, Horimoto KI, Kawaoka Y. 2012. Genetic characterization of H5N1 influenza viruses isolated from chickens in Indonesia in 2010. Vir Gen. 44:459-465.
[OIE] Office International des Epizooties. 2014. Chapter 2.3.4. Avian Influenza. OIE Terrestrial Manual 2014.

Payungporn S, Chutinimitkul S, Chaisingh A, Damrongwatanapokin S, Buranthai C, Amonsin A, Theamboonlers A, Poovorawan Y. 2006. Single step multiplex real-time RT-PCR for H5N1 influenza A virus detection. J Virol Meth. 131:143-147.

Pillai SP, Pantin-Jackwood M, Yassine HM, Saif YM, Lee CW. 2010. The high susceptibility of turkeys to influenza viruses of different origins implies their importance as potential intermediate hosts. Avian Dis. 54:522-526.

Perdue ML. 2008. Molecular determinants of pathogenicity for avian influenza viruses. In: Avian Influenza. Swayne DE, editor. Iowa (IA): Blackwell Publishing.

Qiagen. 2010. QIAamp viral RNA mini handbook, third edition. Valencia (CA): FSC Press.

[SADC] Southern African Development Community (MR). 2010. Detection of avian influenza subtypes $\mathrm{H} 5 / \mathrm{H} 7$ by real-time RT-PCR. SADC Diagnostic Sub-commite.

Spackman E, Suarez DL. 2005. Use of a novel virus inactivation method for multicenter avian influenza realtime reverse transcriptase-polymerase chain reaction proficiency study. J Vet Diagn Invest. 17:76-80.

Spackman E. 2014. Avian influenza virus detection and quantitation by real-time RT-PCR. Methods Mol Biol. 1161:105-118.

Susanti R. 2008. Analisis molekuler fragmen gen penyandi hemaglutinin virus avian influenza subtipe H5N1 dari unggas air (Disertasi). [Bogor (Indones)]: Institut Pertanian Bogor.

Swayne DE, Dennis AS, Beard CW. 1998.A Laboratory manual for the isolation and identification of avian pathogens. 4th ed. Swayne DE, editor. Pennsylvania (PA): American Association of Avian Pathologists.

Tamura K, Peterson D, Peterson N, Stecher G, Nei M, Khumar S. 2011. MEGA5: Molecular evolutionary genetics analysis using maximum likehood, evolutionary distance, and maximum parsimony methods. Mol Biol Evol. 28:2731-2739.

Wanasawaeng W, Bunpapong N, Thanawongnuwech R. 2008. Growth characteristic of the Thai H5N1 avian influenza virus in chicken embryonic eggs and MDCK cells. The 15th Congress of FAVA. Bangkok (Thai): FAVA-OIE Joint Symposium on Emerging Diseases.

Wibawa H, Henning J, Wong F, Selleck P, Junaidi A, Bingham J, Daniels P, Meers J. 2011. A molecular and antigenic survey of $\mathrm{H} 5 \mathrm{~N} 1$ highly pathogenic avian influenza virus isolates from smallholder duck farms in Central Java, Indonesia during 2007-2008. Virol J. 8:117. 
Wibawa H, Prijono WB, Dharmayanti NLPI, Irianingsih SH, Miswati Y, Rohmah A, Andesya E, Romlah, Daulay RSD, Safitria K. 2012. Investigasi wabah penyakit pada itik di Jawa Tengah, Yogyakarta, dan Jawa Timur: identifikasi sebuah clade baru virus Avian Influenza subtipe $\mathrm{H} 5 \mathrm{~N} 1$ di Indonesia. Buletin Laboratorium Veteriner. Balai Besar Veteriner Wates Yogyakarta. 12:2-9.

[WHO] World Health Organization. 2005. Recommended laboratory test to identify avian influenza a virus in specimens from humans.

[WHO] World Health Organization. 2011. Avian influenza situation update in Indonesia.
Yamamoto Y, Nakamura K, Yamada M, Mase M.2010. Comparative pathology of chickens and domestic ducks experimentally infected with highly pathogenic Avian Influenza viruses (H5N1) isolated in Japan in 2007 and 2008. JARQ. 44:73-80.

Zhao G, Gu X, Lu X, Pan J, Duan Z, Zhao K, Gu M, Liu Q, He L, Chen J, Ge S, Wang Y, Chen S, Wang X, Peng D, Wang H, Liu X. 2012. Novel reassortant highly pathogenic $\mathrm{H} 5 \mathrm{~N} 2$ avian influenza viruses in poultry in China. PloS One. 7:1-10. 